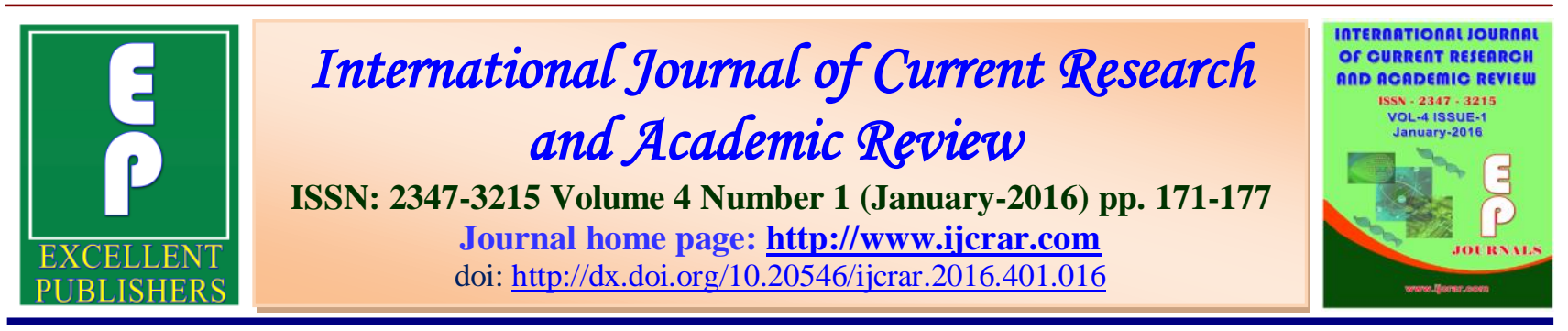

\title{
Consolidating the Dividends of Democracy at the Grassroots: Which way for Human Resources (HR) Practitioners
}

\section{B.I. Nwachukwu*}

Department of Political Science, Faculty of Social Sciences, Imo State University, Owerri, Nigeria

*Corresponding author

\begin{tabular}{|l|l|}
\hline \multirow{2}{*}{$\begin{array}{l}\text { KEYW Dividends of } \\
\text { Democracy at the }\end{array}$} & A B S T R A C T \\
\cline { 2 - 3 } $\begin{array}{l}\text { Grassroots, } \\
\text { (HR) Practitioners }\end{array}$ & $\begin{array}{l}\text { The evolution of democratic regimes in Nigeria has been distorted and } \\
\text { decimated by incessant and cumulatively long years of military rule. Each } \\
\text { military regime introduced and pursued different political and economic } \\
\text { agenda. In appraising the "dividends of democracy", it is crucial to mention } \\
\text { that self-rule granted to Nigeria on October, 1960 was not permitted to thrive. } \\
\text { The military came too soon on the political theatre. And, it is an axiom that } \\
\text { military rule is intrinsically very inefficient essentially because of its unstable } \\
\text { nature. This invariably, marred the country's political journey to democracy. } \\
\text { The disjointed nature of these progressive agenda only left behind, national } \\
\text { woes. The task of redistributing these economic gains for overall national } \\
\text { welfare and development, thus consolidating the dividends of democracy } \\
\text { would therefore, take the form of educating, partnership -and collaboration of } \\
\text { every economic and social agency. It is indeed a major task of the human } \\
\text { resource practitioner. }\end{array}$
\end{tabular}

\section{Introduction}

The right of a nation to determine its political and economic destiny, is subsumed under a democratic dispensation. The foundation of progressive nations has always been based on freedom. The concept of freedom, in perception and limitations, will continue to mean different things to different nations. Every nation owes its ascendancy to its history.
Nations, therefore, are not accidental geographical spaces but planned and well defined sovereign entities.

The evolution of democratic regimes in Nigeria has been distorted and decimated by incessant and cumulatively long years of military rule. Each military regime introduced and pursued different political 
and economic agenda. The disjointed nature of these progressive agenda only left behind, national woes.

What is very visible in these past years is that, corruption became widespread, public funds mismanaged, public property allowed to decay, economic indices in disarray, inflation progressed to double digits and ultimately, the nation's human resources, its live-blood, were not only grossly underutilized, but was undeveloped and allowed to drain away.

The realization of the negative socioeconomic,and political impact of continuous military rule, on the nation, led to series of agitations, locally and internationally, to bring about a home-grown and sustainable democracy (Dudley,1978). Fortunately, this was achieved in 1999. The "civilian to civilian" transition of 2002- will ever remain a landmark achievement in the Nigerian political history (Nanta,2007).

This period has not only refrained the mindset of politically conscious Nigerians, but has also remained the longest period of sustained democratic rule. The dividends of sustained democracy, the world over, will continue to assume an overwhelming popularity over other forms of government.

This paper examines the democratic concept, an appraisal of the performance of the Nigerian economy within the last administration, and the role of human resource practitioners in consolidating the dividends of democracy.

\section{Re-Examining the Concept of Democracy}

Since 1999, the word democracy (Advanced Oxford Dictionary,2000) has become a house-hold name in Nigeria and regularly used in discussion and gatherings. We shall however examine its historical and theoretical perspectives and how practicable democracy is in our National Polity (Civic Education in Nigeria,2006). The word democracy is derived from the Greek word demokratia which means "rule by the people". Again, Abraham Lincoln defined democracy as "government of the people, by the people and for the people". This is probably the most popular definition of democracy. Furthermore, the Oxford Advanced Learner's Dictionary defined democracy as "a system of government in which all the people of a country can vote to elect their representatives". It further stated that democracy is the "fair and equal treatment of everyone in an organization etc. and their right to take part in making decisions".

A critical look at these definitions reveals that for a genuine democracy. To exist (Linderman and Smith,1955).

The government must be by popular opinion. The leaders must be elected from within the people. No person must be denied the right to participate in the election Process. The purpose of elections must be in the interest of the people. There must be fair and equal treatment of all persons.

Further analysis of the above conditions vi'sa-vis the current political situation in Nigeria, clearly puts the national democratic regime at a preliminary stage. Despite these democratic growth problems,' the underlisted principles must be satisfied for any democratic regime to survive (Nwachukwu, 2013; Ugbaja, 2004).

\section{Popular Sovereignty}

This implies that the people must determine and choose who will govern them. The ultimate political power resides with the people. 


\section{Liberty}

Each individual must have the liberty and opportunity to formulate and pursue his own legitimate purposes and aspirations.

The citizens basic freedoms cannot, be abridged except as prescribed under the law.

\section{Rule of Law}

Each person must be guaranteed equal rights under the law whether or not he is occupying any political office. A citizen accused of committing an offence is presumed innocent until proven guilty.

\section{Social Contract}

Men are born free everywhere and not subject to the rule of others except by their own consent. Therefore the basis for a democratic state is the social contract between the individual and the state.

\section{The Franchise}

This is the right of every adult citizen; to vote and be voted for during elections. In a democratic system, this right cannot be denied on the basis of race, ethnic group, sex or social class except in the execution of the verdict of a court of competent jurisdiction.

\section{The Sustenance of Democracy}

There is no doubt that the people of Nigeria want the current democratic dispensation sustained, though with reforms in political and economic processes to enhance service delivery, check capacity under-utilization, reduce corruption and evolve objective political participation. Research studies have shown that the under listed factors will, in no small measure, lead to sustenance of democracy in Nigeria:

\section{Education}

Education confers on the recipients ah ability of critical, objective and independent judgment. The educated has the capacity to liberate himself from basic economic and social problems. This, would place him strategically and independently to support genuine democratic ideals.

\section{Political Awareness}

The individual's cognitive map of his political environment places him in a position to advocate for a positive social change.

\section{Patriotism}

A patriotic citizen will take appropriate measures to defend the interest of his country. It is important to note that when leaders are patriotic, the citizens would naturally follow suit.

De-Monetization of Politics: Though, it is impossible to run political processes without money, structures must be put in place to check the excesses of money politics. Plato advised that political leaders must have nothing to do with the accumulation of wealth (Nwachukwu,2004).

\section{Appraising the Nigerian Economy and "Democracy Dividends"}

When, in May 29 1999 , the elected president of the Federal Republic of Nigeria, Chief Olusegun Obasanjo, gave his inaugural speech, Nigerians were elated and had high hopes that things would change dramatically for the better. In his speech, the president pledged to fight corruption, ease infrastructural bottlenecks, particularly for power and petrol, improve education, healthcare and other basic services, 
Int.J.Curr.Res.Aca.Rev.2016; 4(1): 171-177

accelerate privatization; re-establish government institutions that serve the public.His aims-were to promote private investment, revive the economy and reduce unemployment, while restoring macroeconomic stability and the international community to help deliver a "democracy dividend" to the Nigerian public.

In appraising the "dividends of democracy", it is crucial to mention that self-rule granted to Nigeria on October, 1960 was not permitted to thrive. The military came too soon on the political theatre. And, it is an axiom that military rule is intrinsically very inefficient essentially because of its unstable nature. This invariably, marred the country's political journey to democracy.

On the issue of return of democracy to Nigeria since May 1999, let us note that quite a lot has happened and Nigerians have expressed their freedom in diverse ways. Elections have been rigged generally, but we can not rule out the fact that there were places where people voted freely. And the freedom to vote or not to vote is a freedom that is readily available under democratic dispensation. Let us believe that these are some of the good things that have happened. It is not easy to quantify-all the benefits of democracy. Put differently, the benefits of democracy are both tangible and intangible. .Democracy gives the citizens the unrestricted opportunity to say their mind; to select/elect their leaders; to say no to what they disapprove and the like. In this country, many people talk about the dividends of democracy in terms of infrastructure. This is not what democracy is all about. If the emphasis is on infrastructure alone, then we do not need democracy but dictatorship to provide more infrastructures. History is replete with dictatorships that provided more infrastructures. Democracy provides ample freedom. The challenge is to utilize this freedom responsibly to improve the lot of
Nigeria. We shall also look at tangible benefits of democracy. These include:

\section{The Nigerian Foreign Policy}

The outset of the 1999 administration began with a lot of international diplomatic journeys. These journeys were targeted at restoring diplomatic relations with countries that broke off relationships with Nigeria during periods of military dictatorship. One of such incidence was the suspension of Nigeria as a member of the common wealth of nations in November 1997 due to the murder of Ken Saro-Wiwa (the environmental rights activist) and his compatriots. New bilateral agreements were signed and confidence 'was given to the international community and business organizations" to take advantage of Nigeria's new democratic regime and its potentially good investment profile. Nigerian, citizens abroad were also tipped to come home and join hands with the new government to rebuild Nigeria.

\section{External Debt Management/Repayment}

The repayment of Nigeria's external debt owed to the World Bank and Paris Club by the last administration no doubt breaths a huge air of relief in the Nigerian economy (IMF,2001).The issue of debt servicing, structuring and scheduling had before now constituted a major national debate and source of destruction to other important national issues. Nigeria is however in a better economic credit stance to negotiate trade related agreements with emerging economies of the world. The exploitative and extremely capitalist nature of international monetary organizations like the IMF and World Bank, which before now constituted a major economic setback to Nigeria, and indeed to other developing nations will no longer hunt our national 
budget, balance of payment projections and external reserves.

\section{Privatization of Public Utilities/ Economic Reforms}

There is a general conception among Nigerian civil servants that public property is nobody's property. This belief, has over the years depended and expanded in their psychological framework and has accounted for widespread collapse and decay in almost- all government owned infrastructure. The inconsistencies in government policies only worsened the state of these infrastructures; resulting in poor maintenance culture attached to these facilities. The determination of the last administration to handover the management of some of these facilities to private organizations through privatization has reasonably revitalized some ailing government agencies and parastatals. This is evident in the telecommunication and some aspects of the transport and finance sector.

\section{Deregulation}

The Obasanjo administration reiterated its resolve to place Nigeria boldly in the global economic map by laying a foundation for a competitive and market-based economy. Deregulating the Nigerian economy became very controversial, fuelling series of industrial unrest especially when it encroached on the petroleum sector. There is however, palpable stability in the petroleum sector, with relative product availability.

\section{Political Awareness}

There was very little confidence among Nigerians on the sustenance of democratic government in Nigeria, a decade ago. It is however pertinent to note that the renewed belief' for a sustained democracy has led to increased political participation.This is evident in the number of political parties, number of candidates presented for elections and agitations for balanced political representation at all levels. The increased participation of women in politics is also worth mentioning. This level of awareness will no doubt strengthen the national political base and instill a democratic culture at the grassroots.

\section{Economic Growth}

According to recent IMF report, Nigeria has consistently maintained an average GPD growth of between 5 to $7 \%$ annually over the last 6 years. This shows that national economic growth has remained stable and sustained.

Other developments also saw the reactivation of the financial sector and bank consolidation, solid mineral development and increasing return of life to agriculture and the rural farm economy.

\section{Challenges to Nigeria's "Democracy Dividend"}

Confronting Nigeria's democratic challenges has over the years appeared very elusive. The, list of these challenges would readily over-write the assumed democratic gains and the itemized progress outlined above.

\section{National Security}

A lot of standing controversies place doubts to the-maintenance of National Peace and Security. These issues have continued to linger and have led to colossal wastages of National resources, loss of investment by local and international investors and have placed bold question marks in the Peace and Security of the Nigerian Nation. Such National Security Issues cannot go without mentioning the Niger Delta crises; the inconclusive political reform conference, the ceding of Bakassi Peninsula to the 
Republic of Cameroon, the agitations of the MASSOB, the Boko Haram issue,etc.

\section{Political Stability}

Despite the seemingly persevering nature of this democratic dispensation the last administration witnessed high turnover of public office holders especially in the National assembly. This has not only brought disharmony between the arms of government but generated bad blood and suspicion among government functionaries. It is a fact that the executive was involved in a bitter political battle with the National Assembly, in essence, to delineate the boundaries of their respective authorities. .

\section{Elections}

The structure for election of public officers is far from adequate. Until now, petitions and counter judicial battles on election regularities have continued to trail the Nigerian polity. In the aggregate, the institutions established to conduct elections are too weak to perform the job.

\section{Socio-Economic Structure}

The government has not been able to find solutions to the problem of bad roads, electricity, water supply and affordable healthcare. Other factors include: unemployment, education and housing. Though huge annual budgets have been regularly allocated to these sub-sectors, no visible improvement could be noticed. The setting up of agencies like NAPEP, LEEMP etc. to address the problems of poverty and unemployment only recorded marginal progress in that direction.

\section{Hinderances to Democratic Dividend}

\section{Illiteracy}

Recent World Bank study showed that about $40 \%$ of Nigeria's total population are illiterate. This figure is quite high when compared to the average of $36 \%$ for low and middle income countries. The negative effects of illiteracy in deriving democracy dividends ranges from denied information on available social opportunities to lack of economic will of the individual to actualize his vision and aspirations.

\section{Lack of Good Governance}

one of the cardinal principles needed to deliver democracy dividends is that leaders must be exemplary. Other factors that could hinder democracy dividends in tenure of public office holders, lack of internal security, lack of political cohesion and absence of well planned socioeconomic programmes for local communities.

\section{Consolidating the Dividends of Democracy: the Role of Human Resource (hr) Practttioners}

The task of nation building must bring together all agencies involved in national development. The development of any nation must start with the development of the individual. The role of developing the totality of the individual rests with the human resource practitioner. He charts the course for the translation of the intellect to productive and physically realizable end. The role of the human resource practitioner has remained as important as it is challenging. To effectively deliver democracy dividend, the HR practitioner plays a crucial role among the various agencies of development.

\section{Resource Mobilization}

The human resource practitioner has remained the soul in resource mobilization. Without adequate human resource mobilization, no productive work can be achieved and economic activities would 
cease. Human resource mobilization is practiced in the least levels of every society. However, the task before the professional HR practitioner has become even more challenging.

\section{Capacity Building}

The task of human capital development through capacity building is as important as nation building itself. The continuous development of human capabilities to effectively manage "other productive resources will always remain a critical factor to the realization of the dividends of democracy.

\section{Advisory Functions}

Recent developments relating to neweconomic policies, in Nigeria, and indeed the world at large, have shown that government alone cannot effectively manage its human and material, resources. The HR practitioner must be willing to offer advisory services especially where prevailing government policies have proved inefficient and defective.

\section{Conclusion}

Nigeria no doubt, is a nation with abundant human and material resources. Nigeria's population, landmass and friendly weather as compared to other African countries is a constant reminder that our resources are not efficiently and effectively managed. The incremental accrual of proceeds of crude oil sales translate to the welfare of the
"Nigerian". The much applauded increases in GDP have also left increasing poverty level especially in our rural communities. The task of redistributing these economic gains for overall national welfare and development, thus consolidating the dividends of democracy would therefore, take the form of educating, partnership and collaboration of every economic and social agency. It is indeed a major task of the human resource practitioner.

\section{References}

Dudley B. 1978. Instability and Political Order. Ibadan: Ibandan University Press. Lindeman,E.C and Smith, T.V. (1955): The Democratic Way of Life. New York: Mentor Books

IMF Report on the State of the Nigerian Economy.2001.

Ugbaja, C.I. 2004. Elements of Government: The Nigerian Perspective. Owerri: Bon Publication.

Oxford Advanced Learners Dictionary. $2000.6^{\text {th }}$ Edition.

Nanta,E.2007.The Nigeria Election.Enugu.

Civic Education in Nigeria.2006.A Source Book.National Technical Committe on Civic Education.

Nwachukwu,C.B.2013.Themes and Concept in Government II.Imo State University,Owerri.

Nwachukwu,C.B.2004.Themes and Concept in Government I. State University, Owerri.

\section{How to cite this article:}

Nwachukwu. B.I. 2016. Consolidating the Dividends of Democracy at the Grassroots: Which way for Human Resources (HR) Practitioners. Int.J.Curr.Res.Aca.Rev. 4(1): 171-177. doi: http://dx.doi.org/10.20546/ijcrar.2016.401.016 